\title{
Comparison of haemodynamic effects of phentolamine, sodium nitroprusside, and glyceryl trinitrate in acute myocardial infarction
}

\author{
V. KÖTTER, E. R. VON LEITNER, J. WUNDERLICH, AND R. SCHRÖDER \\ From the Department of Cardiology and Pulmonology of the Medizinische Klinik und Poliklinik der \\ Freien Universität Berlin, Hindenburgdamm 30, 1 Berlin 45, Germany
}

The effects of the commonly employed systemic vasodilators phentolamine, nitroprusside, and intravenous glyceryl trinitrate on cardiac performance, peripheral resistance, and vascular capacitance, as judged by changes in left ventricular filling pressure, were compared in 29 patients studied within 24 hours after the onset of acute myocardial infarction. To provide a common basis for comparison the mean arterial pressure was lowered to the same level of about $80 \mathrm{mmHg}$ in the previously normotensive patients and 90 to 100 $\mathrm{mmHg}$ in the patients with a history of hypertension, respectively. To provide a direct comparison in the same patients, of 20 patients treated with nitroprusside, 12 were also treated with nitroglycerin; 8 patients were given nitroprusside as well as phentolamine.

Phentolamine produced a highly significant increase in cardiac index, stroke volume index, and heart rate. Overall nitroprusside did not produce significant changes of the same indices, but in patients with a cardiac index less than $2.5 \mathrm{l} / \mathrm{min}$ per $\mathrm{m}^{2}$ an increase in cardiac index was noted. Glyceryl trinitrate, however, produced a significant decrease in cardiac index and stroke volume index.

Total systemic vascular resistance declined most during phentolamine administration, from 21.0 to $11 \cdot 2$ units, during nitroprusside from $21 \cdot 8$ to 15.2, and during glyceryl trinitrate from 19.9 to 17.4. Compared with nitroprusside, in the same subject, the greater effect of phentolamine, and the lesser one of glyceryl trinitrate, on the total systemic vascular resistance were statistically significant.

The ratio $\Delta$ per cent left ventricular filling pressure/ $\Delta$ per cent systemic vascular resistance rose considerably with glyceryl trinitrate since a large decrease in left ventricular filling pressure was opposed by only a minor decrease of systemic vascular resistance. Phentolamine, because of its greater effect in decreasing systemic vascular resistance leads to a small decline in the ratio. Nitroprusside led to an increase in the ratio $\Delta$ per cent left ventricular filling pressure/ $\Delta$ per cent systemic vascular resistance which fell between the effects of the other two agents, but which was closer to the effect of phentolamine.

The results indicate that nitroprusside had the most beneficial effect in the patients studied. Vasodilator therapy for acute myocardial infarction, however, should be limited to patients with high blood pressure and/or pump failure and pulmonary congestion until its local effect on the acute ischaemic myocardium is better understood.

Several reports have been published on the treatment of congestive heart failure or acute myocardial infarction with various vasodilator drugs (Gould et al., 1969; Franciosa et al., 1972; Chatterjee et al., 1973; Kelly et al., 1973; Gould et al., 1974; Walinsky et al., 1974; Come et al., 1975; da Luz et al., 1975; von Leitner et al., 1975; Williams et al., 1975; Bussmann et al., 1976; Miller et al., 1976). Though the value of left ventricular unloading in improving cardiac performance is well documented, Received for publication 15 April 1977 it is not known whether a given vasodilator agent has characteristic properties which are unique and which confer relative advantages in different clinical settings.

To our knowledge only one study has been performed to evaluate the characteristic properties of sodium nitroprusside, and glyceryl trinitrate by comparing the effects of these two agents on the same patient (Armstrong et al., 1975). Accordingly, the present investigation was carried out to quantify and compare the effects of intravenous phentol- 
amine and nitroprusside, or nitroprusside and glyceryl trinitrate, respectively, with the mean arterial pressure lowered to and adjusted at an identical level in the same patient.

\section{Methods}

Twenty-nine patients between 26 and 80 years, mean age 62.3 years, were examined within 24 hours after the onset of symptoms of acute transmural myocardial infarction, documented by a typical history, electrocardiographic findings, and serum enzyme changes. The nature and purpose of the treatment and the associated studies were explained to each patient. Of the patients, 21 were men and 8 were women. The average time from the onset of symptoms to the first haemodynamic measurements was 10.25 \pm 0.8 hours. Nineteen had anterior infarction and 10 had inferior myocardial infarction. Patients with rhythm disturbances were excluded from this study.

Pulmonary arterial catheterisation was performed at the bedside using a Swan-Ganz flow-directed balloon catheter ${ }^{1}$ inserted percutaneously through the femoral vein. With gas sterilisation the catheters could be used 4 to 5 times. Cardiac output was determined by a thermodilution technique using injections of ice-cold 5 per cent glucose and a cardiac output computer. ${ }^{2}$ The mean value of at least three measurements was computed; the stroke volume was derived using the heart rate counted each time. The pulmonary arterial pressure was measured through the same triple-lumen catheter. The arterial pressure was measured by means of a catheter introduced percutaneously from the femoral artery into the descending aorta. Mean pressures were obtained from an electronically integrated record. Recordings were made with a transportable ultraviolet light recorder. ${ }^{3}$ Phasic pressure measurements were averaged over two whole respiratory cycles. The common zero reference level for all pressures was set at $5 \mathrm{~cm}$ below the sternal angle, with the patient supine. All measurements were made in the patient's room.

Measurements used to evaluate the cardiocirculatory changes included the following:

Stroke volume index $(\mathrm{SVI})=$ stroke volume/body surface area $\left(\mathrm{ml} / \mathrm{m}^{2}\right)$

Systemic vascular resistance $(\mathrm{SVR})=$ mean arterial pressure (MAP)/cardiac output (CO) (arbitrary units)

Mean per cent decrease in left ventricular filling pressure/mean per cent decrease in SVR ( $\Delta \%$

${ }^{1}$ Model No. 93A-118-F: Edwards Laboratories Inc.

${ }^{2}$ Model 9510: Edwards Laboratories Inc.

35-127 recording oscillograph: Bell and Howell.
LVFP $/ \Delta \%$ SVR), where LVFP= diastolic pulmonary arterial pressure.

Statistical analyses were performed using Student's $t$ test with paired comparisons.

\section{VASODILATOR THERAPY}

Phentolamine, nitroprusside, and glyceryl trinitrate were administered intravenously by constant infusion pump ${ }^{4}$ via a centrally placed venous catheter. Step by step increases in the dose were made at 3 to 5 minute intervals until a mean systemic arterial pressure of about $80 \mathrm{mmHg}$ was reached. The infusion rate then was kept constant, or adjusted appropriately if necessary, to maintain a constant arterial pressure in the same patient. In 6 patients with known hypertension, the mean arterial pressure was lowered to 90 to $100 \mathrm{mmHg}$ only. The average dosages needed were: phentolamine 1.34 $\mathrm{mg} / \mathrm{min}$ (range, 0.4 to $5.0 \mathrm{mg} / \mathrm{min}$ ); nitroprusside $88 \mu \mathrm{g} / \mathrm{min}$ (range, 33 to $273 \mu \mathrm{g} / \mathrm{min}$ ); glyceryl trinitrate $50 \mu \mathrm{g} / \mathrm{min}$ (range, 8.3 to $117 \mu \mathrm{g} / \mathrm{min}$ ).

Haemodynamic measurements were made 30 and 15 minutes before starting the drug infusion and repeated 15 and 30 minutes after the desired arterial blood pressure and a stable circulatory state had been obtained. There was always at least one hour without any vasodilator treatment between the administration of two different drugs for comparison. To make direct comparisons in the same subject 8 of 20 patients treated with nitroprusside also received phentolamine and 12 also received glyceryl trinitrate. Eight patients treated with phentolamine only and one patient treated with glyceryl trinitrate only were included for the better evaluation of the specific effect of each single drug. At the time of the study the patients were not receiving any other therapy.

\section{Results}

The results of direct comparisons in the same patients are summarised in Tables 1 and 2 and in Fig. 1 and 2. The combined results in all the patients investigated are summarised in Table 3 and in Fig. 3 and 4.

\section{(1) LEFT VENTRICULAR FILLING PRESSURE (LVFP)}

When directly compared in the same patient, nitroprusside was more effective in decreasing the filling pressure than phentolamine (Fig. 1, Table 1). Comparing nitroprusside and glyceryl trinitrate in the same patient, no difference could be shown (Fig. 2, Table 2). When all patients investigated were considered, the smaller effect of phentolamine 'Infusomat: Braun, Melsungen. 

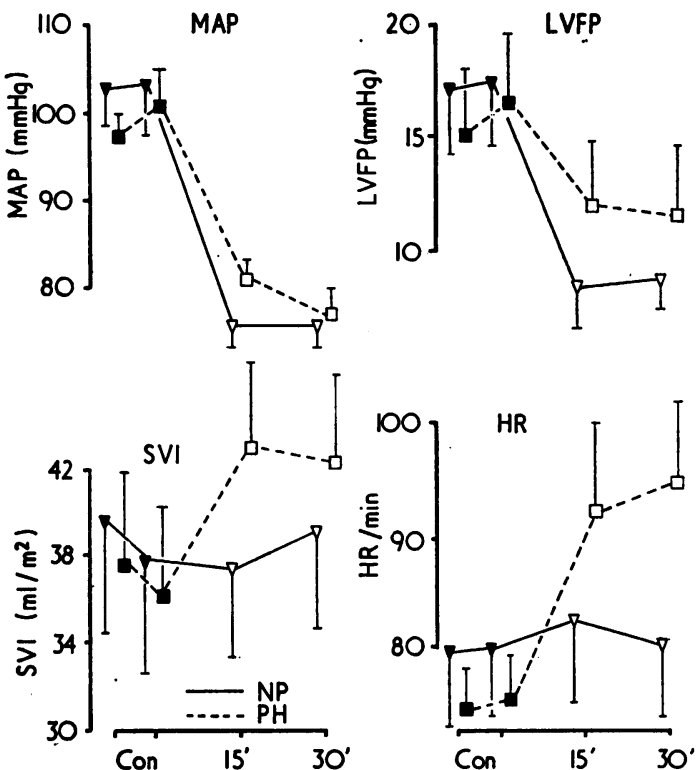

Fig. 1 Comparison of the effects of phentolamine (PH) and sodium nitroprusside (NP) on haemodynamic variables in the same individuals $(n=8)$. MAP, mean arterial pressure, SVI, stroke volume index; LVFP, left ventricular filling pressure; HR, heart rate. Closed symbols, control measurements 30 and 15 minutes before therapy. Open symbols, 15 and 30 minutes measurements after reaching the desired mean atrial blood pressure. (Means \pm standard error of mean.)
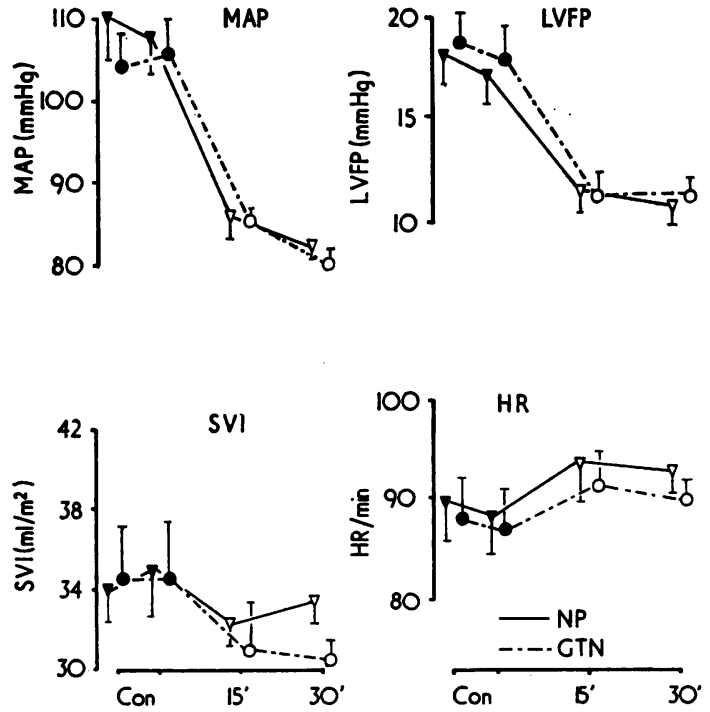

in decreasing the filling pressure was not apparent (Table 3, Fig. 4). This is because in those patients treated with nitroprusside in comparison with phentolamine, or treated with phentolamine only, the mean arterial pressure was generally lowered somewhat more.

(2) HEART RATE (HR)

During the infusion of glyceryl trinitrate or nitroprusside there was only a slight rise in heart rate. During administration of phentolamine, however, distinct increase in heart rate was observed (Table 3, Fig. 1).

(3) STROKE VOLUME INDEX (SVI)

On the average no significant change in stroke volume index was seen during infusion of nitroprusside. Phentolamine, however, produced significant increases in stroke volume index, which in all 16 patients investigated averaged $5.0 \mathrm{ml} / \mathrm{m}^{2}(P<$ 0.001 ). Glyceryl trinitrate, on the other hand, produced a significant decrease in stroke volume index from $35.2 \pm 2.0$ to $31.0 \pm 1.9 \mathrm{ml} / \mathrm{m}^{2}$ (Table 3) and a mean difference of $3 \mathrm{ml} / \mathrm{m}^{2}$ when compared with the effect of nitroprusside in the same patient (Table 2).

(4) CARDIAC INDEX (CI)

In 20 patients nitroprusside caused only a small and nonsignificant increase of cardiac index. This increase was not dependent upon the initial left

Fig. 2 Comparison of the effects of sodium nitroprusside (NP) and glyceryl trinitrate (GTN) on haemodynamic variables in the same subjects $(n=12)$. Abbreviations, etc., as in Fig. 1. 
Table 1 Comparison of effects of sodium nitroprusside (NP) and phentolamine (PH) on haemodynamic variables in same individuals $(n=8)$

\begin{tabular}{|c|c|c|c|c|c|c|c|c|}
\hline & $H R / \min$ & $\begin{array}{l}S B P \\
(m m H g)\end{array}$ & $\begin{array}{l}D B P \\
(m m H g)\end{array}$ & $\begin{array}{l}M A P \\
(m m H g)\end{array}$ & $\begin{array}{l}L V F P \\
(m m H g)\end{array}$ & $\begin{array}{l}C I \\
\left(l / \min \text { per } m^{2}\right)\end{array}$ & $\begin{array}{l}S V I \\
\left(m l / m^{2}\right)\end{array}$ & $\begin{array}{l}\text { SVR } \\
\text { (units) }\end{array}$ \\
\hline $\mathrm{C}_{\mathrm{I}}$ & $\begin{array}{l}80 \cdot 3^{\star} \\
\pm 5 \cdot 7\end{array}$ & $\begin{array}{r}139.6 \\
\pm 6.4\end{array}$ & $\begin{array}{r}80 \cdot 4 \\
\pm 5 \cdot 2\end{array}$ & $\begin{array}{r}102 \cdot 6 \\
\pm 7 \cdot 0\end{array}$ & $\begin{array}{l}17 \cdot 3 \\
\pm 3 \cdot 0\end{array}$ & $\begin{array}{l}3.0 \\
\pm 0.35\end{array}$ & $\begin{array}{r}39 \cdot 5 \\
\pm 5 \cdot 0\end{array}$ & $\begin{array}{r}22.0 \\
\pm 3.4\end{array}$ \\
\hline $\mathrm{C}_{\text {II }}$ & $\begin{array}{r}80.5 \\
\pm 5.9\end{array}$ & $\begin{array}{r}145 \cdot 3 \\
\pm 7 \cdot 0\end{array}$ & $\begin{array}{r}80.9 \\
\pm 6.2\end{array}$ & $\begin{array}{r}103.0 \\
\pm 6.6\end{array}$ & $\begin{array}{r}17 \cdot 5 \\
\pm 2 \cdot 9\end{array}$ & $\begin{array}{c}2.9 \\
\pm 0.36\end{array}$ & $\begin{array}{r}37 \cdot 6 \\
\pm 5 \cdot 0\end{array}$ & $\begin{array}{r}23 \cdot 2 \\
\pm 3 \cdot 4\end{array}$ \\
\hline $\mathrm{NP}_{15}$ & $\begin{array}{r}83.4 \\
\pm 7.0\end{array}$ & $\begin{array}{r}106.4 \\
\pm 1.7\end{array}$ & $\begin{array}{r}62.5 \\
\pm 3.0\end{array}$ & $\begin{array}{r}76 \cdot 1 \\
\pm 2 \cdot 3\end{array}$ & $\begin{array}{r}8 \cdot 0 \\
\pm 2 \cdot 1\end{array}$ & $\begin{array}{r}3.0 \\
\pm 0.3\end{array}$ & $\begin{array}{l}37 \cdot 4 \\
\pm 4 \cdot 2\end{array}$ & $\begin{array}{r}15.6 \\
\pm 1.4\end{array}$ \\
\hline $\mathrm{NP}_{\mathbf{3 0}}$ & $81 \cdot 1$ & 106.4 & 61.9 & 76.0 & $8 \cdot 5$ & $3 \cdot 1$ & $39 \cdot 2$ & $15 \cdot 1$ \\
\hline & $\begin{array}{l} \pm 5.6 \\
75.4\end{array}$ & $\begin{array}{r} \pm 2 \cdot 6 \\
138.4\end{array}$ & \pm 3.0 & $\pm 2 \cdot 7$ & \pm 1.4 & \pm 0.3 & \pm 3.8 & \pm 1.5 \\
\hline $\mathrm{C}_{\text {III }}$ & $\begin{array}{r}75.4 \\
\pm 3.5\end{array}$ & & $\begin{array}{r}75 \cdot 3 \\
\pm 3 \cdot 2\end{array}$ & $\begin{array}{r}96.9 \\
\pm 3.1\end{array}$ & $\begin{array}{r}14.8 \\
\pm 3.0\end{array}$ & $\begin{array}{c}2.7 \\
\pm 0.26\end{array}$ & $\begin{array}{l}37 \cdot 2 \\
\pm 4 \cdot 7\end{array}$ & $\begin{array}{l}22.4 \\
\pm 2.7\end{array}$ \\
\hline $\mathrm{C}_{\text {IV }}$ & $\begin{array}{r}75.9 \\
+3.7\end{array}$ & $\begin{array}{r}142.9 \\
+4.2\end{array}$ & $\begin{array}{r}78.6 \\
+3.9\end{array}$ & $\begin{array}{r}101.0 \\
+4.5\end{array}$ & $\begin{array}{r}16.5 \\
+3.2\end{array}$ & $2 \cdot 6$ & 35.8 & 23.9 \\
\hline $\mathrm{PH}_{15}$, & 93.3 & $\begin{array}{r} \pm 4 \cdot 2 \\
120.0\end{array}$ & $\begin{array}{r} \pm 3.9 \\
61.5\end{array}$ & $\begin{array}{r} \pm 4.5 \\
80.8\end{array}$ & $\begin{array}{r} \pm 3.2 \\
11.8\end{array}$ & $\begin{array}{c} \pm 0 \cdot 24 \\
3.8\end{array}$ & $\begin{array}{r} \pm 4.4 \\
43.4\end{array}$ & $\begin{array}{l} \pm 2.8 \\
12.8\end{array}$ \\
\hline & $\pm 7 \cdot 7$ & $\pm 5 \cdot 4$ & \pm 3.6 & $\pm 3 \cdot 2$ & $\pm 3 \cdot 1$ & \pm 0.29 & \pm 4.8 & $\pm 1 \cdot 3$ \\
\hline $\mathrm{PH}_{30}$, & $96 \cdot 1$ & $112 \cdot 9$ & $60 \cdot 0$ & $77 \cdot 0$ & 11.4 & 3.9 & 42.4 & $12 \cdot 1$ \\
\hline \multirow{2}{*}{$\begin{array}{l}P \text { values: } \\
\mathrm{C}_{\mathrm{II}}-\mathrm{C}_{\mathrm{IV}} \\
\mathrm{NP}_{15},-\mathrm{PH}_{15^{\prime}} \\
\mathrm{NP}_{30},-\mathrm{PH}_{30^{\prime}}\end{array}$} & & & & & & & & \\
\hline & $\begin{array}{l}\text { NS } \\
<0.05 \\
<0.025\end{array}$ & $\begin{array}{l}\text { NS } \\
<0.05 \\
\text { NS }\end{array}$ & $\begin{array}{l}\text { NS } \\
\text { NS } \\
\text { NS }\end{array}$ & $\begin{array}{l}\text { NS } \\
<0.025 \\
\text { NS }\end{array}$ & $\begin{array}{l}\text { NS } \\
<0.025 \\
\text { NS }\end{array}$ & $\begin{array}{l}\text { NS } \\
<0.02 \\
<0.02\end{array}$ & $\begin{array}{l}\text { NS } \\
<0.025 \\
\text { NS }\end{array}$ & $\begin{array}{l}\text { NS } \\
<0.02 \\
<0.01\end{array}$ \\
\hline
\end{tabular}

*All values represent means \pm standard errors of the mean.

Abbreviations: $\mathrm{C}_{\mathrm{I}}$ to $\mathrm{C}_{\mathrm{IV}}$, control measurements; $\mathrm{NP}_{15}$, and $\mathrm{NP}_{30}$; $\mathrm{PH}$ and $\mathrm{PH}_{15}$, measurements 15 and 30 minutes after constant conditions had been obtained under nitroprusside infusion and phentolamine, respectively. HR, heart rate; SAP, systolic blood pressure; DBP, diastolic blood pressure; MAP, mean arterial pressure; LVFP, left ventricular filling pressure; CI, cardiac index; SVI, stroke volume index; SVR, systemic vascular resistance.

Table 2 Comparison of effects of sodium nitroprusside (NP) and glyceryl trinitrate (GTN) on haemodynamic variables in same individuals $(n=12)$

\begin{tabular}{|c|c|c|c|c|c|c|c|c|}
\hline & $H R / \min$ & $\begin{array}{l}S B P \\
(m m H g)\end{array}$ & $\begin{array}{l}D B P \\
(m m H g)\end{array}$ & $\begin{array}{l}M A P \\
(m m H g)\end{array}$ & $\begin{array}{l}L V F P \\
(m m H g)\end{array}$ & $\begin{array}{l}C I \\
\left(l / \min \text { per } m^{2}\right)\end{array}$ & $\begin{array}{l}S V I \\
\left(m l / m^{2}\right)\end{array}$ & $\begin{array}{l}\text { SVR } \\
\text { (units) }\end{array}$ \\
\hline $\begin{array}{l}\mathrm{C}_{I} \\
\mathrm{C}_{\mathrm{II}} \\
\mathrm{NP}_{15^{\prime}} \\
\mathrm{NP}_{\mathbf{3 0}} \\
\mathrm{C}_{\mathrm{III}} \\
\mathrm{C}_{\mathrm{IV}} \\
\mathrm{GTN}_{15^{\prime}} \\
\mathrm{GTN}_{30^{\prime}}\end{array}$ & $\begin{array}{c}89.8 \star \\
\pm 3.9 \\
88.1 \\
\pm 4.1 \\
93.7 \\
\pm 3.2 \\
93.1 \\
\pm 3.5 \\
87.6 \\
\pm 4.2 \\
87.9 \\
\pm 3.7 \\
91.3 \\
\pm 3.9 \\
90.5 \\
\pm 3.8\end{array}$ & $\begin{array}{r}152 \cdot 1 \\
\pm 7 \cdot 0 \\
151 \cdot 2 \\
\pm 7 \cdot 3 \\
119 \cdot 5 \\
\pm 3 \cdot 7 \\
114 \cdot 8 \\
\pm 2 \cdot 7 \\
141 \cdot 9 \\
\pm 5 \cdot 7 \\
146 \cdot 2 \\
\pm 7 \cdot 7 \\
114 \cdot 1 \\
\pm 2 \cdot 8 \\
111 \cdot 4 \\
\pm 3.0\end{array}$ & $\begin{array}{r}83 \cdot 0 \\
\pm 4.0 \\
85 \cdot 1 \\
\pm 4 \cdot 1 \\
70 \cdot 4 \\
\pm 2 \cdot 6 \\
67 \cdot 4 \\
\pm 2 \cdot 6 \\
78 \cdot 3 \\
\pm 3 \cdot 5 \\
79 \cdot 3 \\
\pm 3 \cdot 8 \\
70 \cdot 2 \\
\pm 2 \cdot 2 \\
67 \cdot 3 \\
\pm 2.7\end{array}$ & $\begin{array}{r}110.0 \\
\pm 5.0 \\
108.6 \\
\pm 5 \cdot 2 \\
86.4 \\
\pm 3 \cdot 2 \\
82.6 \\
\pm 2 \cdot 2 \\
104 \cdot 8 \\
\pm 4 \cdot 1 \\
105 \cdot 4 \\
\pm 5 \cdot 1 \\
85 \cdot 1 \\
\pm 1 \cdot 7 \\
80.3 \\
\pm 2.2\end{array}$ & $\begin{array}{r}18.2 \\
\pm 1.3 \\
17.8 \\
\pm 1.3 \\
11.7 \\
\pm 1.2 \\
10.8 \\
\pm 0.8 \\
18.7 \\
\pm 1.6 \\
18.5 \\
\pm 1.5 \\
11.5 \\
\pm 1.1 \\
11.3 \\
\pm 1.1\end{array}$ & $\begin{array}{c}3.0 \\
\pm 0.17 \\
3.0 \\
\pm 0.19 \\
3.1 \\
\pm 0.16 \\
3.1 \\
\pm 0.14 \\
3.0 \\
\pm 0.20 \\
3.0 \\
\pm 0.17 \\
2.8 \\
\pm 0.14 \\
2.7 \\
\pm 0.14\end{array}$ & $\begin{array}{c}34.1 \\
\pm 1.8 \\
35.0 \\
\pm 2.2 \\
32.6 \\
\pm 1.8 \\
33.7 \\
\pm 1.8 \\
34.5 \\
\pm 2.3 \\
35.3 \\
\pm 2.3 \\
31.3 \\
\pm 2.2 \\
30.6 \\
\pm 1.8\end{array}$ & $\begin{array}{r}20.8 \\
\pm 1.5 \\
20.7 \\
\pm 1.5 \\
16.3 \\
\pm 1.0 \\
15.2 \\
\pm 0.8 \\
20.3 \\
\pm 1.6 \\
19.9 \\
\pm 1.4 \\
17.5 \\
\pm 1.2 \\
17.3 \\
\pm 1.2\end{array}$ \\
\hline $\begin{array}{l}P \text { values } \\
\mathrm{C}_{\mathrm{II}}-\mathrm{C}_{\mathrm{IV}} \\
\mathrm{NP}_{15^{\prime}}-\mathrm{GTN}_{18}, \\
\mathrm{NP}_{30},-\mathrm{GTN}_{30},\end{array}$ & $\begin{array}{l}\text { NS } \\
\text { NS } \\
\text { NS }\end{array}$ & $\begin{array}{l}\text { NS } \\
<0.02 \\
\text { NS }\end{array}$ & $\begin{array}{l}<0.005 \\
\text { NS } \\
\text { NS }\end{array}$ & $\begin{array}{l}\text { NS } \\
\text { NS } \\
\text { NS }\end{array}$ & $\begin{array}{l}\text { NS } \\
\text { NS } \\
\text { NS }\end{array}$ & $\begin{array}{l}\text { NS } \\
<0.025 \\
<0.001\end{array}$ & $\begin{array}{l}\text { NS } \\
\text { NS } \\
<0.005\end{array}$ & $\begin{array}{l}\text { NS } \\
\text { NS } \\
<0.02\end{array}$ \\
\hline
\end{tabular}

*All values represent means \pm standard errors of the mean.

Abbreviations as for Table 1 .

ventricular filling pressure before treatment (Fig. 3). It is possible that this effect was, however, related to the initial cardiac index, since the 5 patients with an index below $2.5 \mathrm{l} / \mathrm{min}$ per $\mathrm{m}^{2}$ during therapy did show an increase in cardiac index. Phentolamine in all patients resulted in a highly significant increase in cardiac index, the average being $1.01 / \mathrm{min}$ per $\mathrm{m}^{2}$.
Glyceryl trinitrate infusion resulted in a significant decrease in the cardiac index, from an average of $3.0 \pm 0 \cdot 1$ to $2 \cdot 8 \pm 0 \cdot 1 \mathrm{l} / \mathrm{min}$ per $\mathrm{m}^{2}$ (Table 3 ). These effects were not apparently dependent upon the initial filling pressure (Fig. 3). Compared with the same patients, the increase in cardiac index with phentolamine and the decrease with glyceryl 
Table 3 Summary of haemodynamic data of all patients: results after therapy in each patient are mean values of measurements after 15 and 30 minutes during constant conditions

\begin{tabular}{|c|c|c|c|c|c|c|c|c|}
\hline & $H R / \min$ & $\begin{array}{l}S B P \\
(\operatorname{mmHg})\end{array}$ & $\begin{array}{l}D B P \\
\left(m m H_{g}\right)\end{array}$ & $\begin{array}{l}M A P \\
(m m H g)\end{array}$ & $\begin{array}{l}L V F P \\
(m m H g)\end{array}$ & $\begin{array}{l}C I \\
\left(l / m i n \text { per } m^{2}\right)\end{array}$ & $\underset{\left(m l / m^{2}\right)}{S V I}$ & $\begin{array}{c}S V R \\
\text { (units) }\end{array}$ \\
\hline $\begin{array}{l}\text { C } \\
\text { NP }(n=20) \\
\text { C } \\
\text { PH }(n=16) \\
\text { C } \\
\operatorname{GTN}(n=13)\end{array}$ & $\begin{array}{l}85 \cdot 3 \star \\
\pm 3 \cdot 5 \\
88 \cdot 6 \\
\pm 3 \cdot 3 \\
81 \cdot 6 \\
\pm 3 \cdot 5 \\
98 \cdot 4 \\
\pm 5 \cdot 2 \\
88 \cdot 0 \\
\pm 3 \cdot 4 \\
91 \cdot 1 \\
\pm 3 \cdot 4\end{array}$ & $\begin{array}{r}148 \cdot 0 \\
\pm 5 \cdot 0 \\
110 \cdot 0 \\
\pm 2 \cdot 1 \\
147 \cdot 7 \\
\pm 4 \cdot 9 \\
114 \cdot 4 \\
\pm 4 \cdot 1 \\
146 \cdot 6 \\
\pm 7 \cdot 1 \\
114 \cdot 1 \\
\pm 2 \cdot 5\end{array}$ & $\begin{array}{r}82.9 \\
\pm 3 \cdot 4 \\
65 \cdot 1 \\
\pm 1 \cdot 7 \\
80.0 \\
\pm 3 \cdot 1 \\
60 \cdot 4 \\
\pm 2 \cdot 4 \\
80.0 \\
\pm 3 \cdot 5 \\
70 \cdot 2 \\
\pm 2.2\end{array}$ & $\begin{array}{c}105 \cdot 6 \\
\pm 4 \cdot 0 \\
79 \cdot 70 \\
\pm 1 \cdot 7 \\
106 \cdot 5 \\
\pm 4 \cdot 3 \\
78 \cdot 0 \\
\pm 2 \cdot 0 \\
105 \cdot 6 \\
\pm 4 \cdot 7 \\
84 \cdot 6 \\
\pm 1 \cdot 7\end{array}$ & $\begin{array}{r}18.1 \\
\pm 1.4 \\
10.3 \\
\pm 0.9 \\
18.1 \\
\pm 1.8 \\
10.4 \\
\pm 1.7 \\
18.6 \\
\pm 1.4 \\
11.8 \\
\pm 1.1\end{array}$ & $\begin{array}{c}2.9 \\
\pm 0.17 \\
3.1 \\
\pm 0.14 \\
2.9 \\
\pm 0.14 \\
3.9 \\
\pm 0.14 \\
3.0 \\
\pm 0.14 \\
2.8 \\
\pm 0.14\end{array}$ & $\begin{array}{r}35.6 \\
\pm 2.4 \\
35.4 \\
\pm 2.0 \\
36.7 \\
\pm 2.5 \\
41.7 \\
\pm 2.8 \\
35 \cdot 2 \\
\pm 2.0 \\
31.0 \\
\pm 1.9\end{array}$ & $\begin{array}{r}21 \cdot 8 \\
\pm 1.6 \\
15 \cdot 2 \\
\pm 0.7 \\
21 \cdot 0 \\
\pm 1.7 \\
11 \cdot 2 \\
\pm 0.7 \\
19.9 \\
\pm 1.2 \\
17.4 \\
\pm 1.3\end{array}$ \\
\hline $\begin{array}{l}\text { P values } \\
\text { C-NP } \\
\text { C-PH } \\
\text { C-GTN }\end{array}$ & $\begin{array}{l}\text { NS } \\
<0.001 \\
\text { NS }\end{array}$ & $\begin{array}{l}<0.001 \\
<0.001 \\
<0.001\end{array}$ & $\begin{array}{l}<0.001 \\
<0.001 \\
<0.001\end{array}$ & $\begin{array}{l}<0.001 \\
<0.001 \\
<0.001\end{array}$ & $\begin{array}{l}<0.001 \\
<0.001 \\
<0.001\end{array}$ & $\begin{array}{l}\text { NS } \\
<0.001 \\
<0.05\end{array}$ & $\begin{array}{l}\text { NS } \\
<0.001 \\
<0.005\end{array}$ & $\begin{array}{l}<0.001 \\
<0.001 \\
<0.001\end{array}$ \\
\hline
\end{tabular}

*All values represent means \pm standard errors of the mean.

Abbreviations: C, control; NP, Na-nitroprusside; PH, phentolamine; GTN, glyceryl trinitrate.

trinitrate were significantly different from the overall lack of effect on cardiac index during nitroprusside infusion (Tables 1 and 2).

(5) RATIO $\Delta \%$ LVFP/ $\Delta \%$ SVR

All three agents lowered the systemic vascular resistance, the greatest effect being the decrease during phentolamine infusion (from 21.0 \pm 1.7 to $11 \cdot 2 \pm 0 \cdot 7)$, and the least with glyceryl trinitrate (from $19.9 \pm 1.2$ to $17 \cdot 4 \pm 1 \cdot 3$ ) (Table 3).

Use of the ratio $\Delta \% \mathrm{LVFP} / \Delta \% \mathrm{SVR}$, relating the percentage reduction in filling pressure to that of vascular resistance allows comparison of the results obtained in all patients investigated. Administration of glyceryl trinitrate yielded a high value, since a pronounced decrease in filling pressure was associated with only a minor decrease in vascular resistance. By contrast, phentolamine, because of the distinct decrease in vascular resistance, yielded only a small decrease in the ratio. The effect of nitroprusside occupied an intermediate position but closer to that of phentolamine than that of glyceryl trinitrate (Fig. 4).

\section{Discussion}

The dramatic circulatory response to vasodilator agents and the experimental evidence that such therapy may reduce infarct size (Shell et al., 1973) have led to the suggestion that vasodilator therapy might represent rational treatment for all patients with acute myocardial infarction. This investigation examines the contrasting effects on cardiac performance, on the peripheral resistance, and on vascular capacitance of the three commonly em- ployed ventricular unloading agents phentolamine, sodium nitroprusside, and glyceryl trinitrate. In order to have a common basis for comparison in each individual patient, the mean arterial pressure was brought to the same level of about $80 \mathrm{mmHg}$ in the previously normotensive patients and of 90 to $100 \mathrm{mmHg}$ in patients with a history of hypertension, respectively.

Phentolamine administration in all patients resulted in a pronounced increase in cardiac index and stroke volume index (Table 3 and Fig. 3). The heart rate also rose significantly. Since such changes could be detected in only a few patients when identical reductions in the arterial pressure had been produced by infusion of nitroprusside or glyceryl trinitrate, these effects of phentolamine cannot be based only on the decrease in the afterload, or be explained simply by reflex mechanisms. Apparently, phentolamine possesses a positive inotropic and chronotropic effect independent of the lowering of the arterial pressure. Though the greatest reduction in peripheral resistance was produced by phentolamine, which should result in a greater reduction of impedance to the left ventricular ejection, and be expected to allow better systolic emptying, the increase in cardiac index and heart rate did not seem to follow the reduction of arterial pressure. Furthermore, as found by Gould et al. (1969), in some patients we observed that with small doses of phentolamine the decrease in the peripheral resistance was balanced by increases of stroke volume index and heart rate, so that reduction in the blood pressure could only be achieved by larger doses of phentolamine, or by the addition of small doses of practolol (von Leitner et al., 1975). 
Accordingly, the doses used by us (an average of $1.34 \mathrm{mg} / \mathrm{min}$ ) seem to be relatively high but have also been reported by other authors (Miller et al., 1976).

Experimental animal studies have suggested that a cardiac stimulatory effect of phentolamine is mediated via catecholamines (Dairman et al., 1968; Bagwell et al., 1970; Singh et al., 1970), though
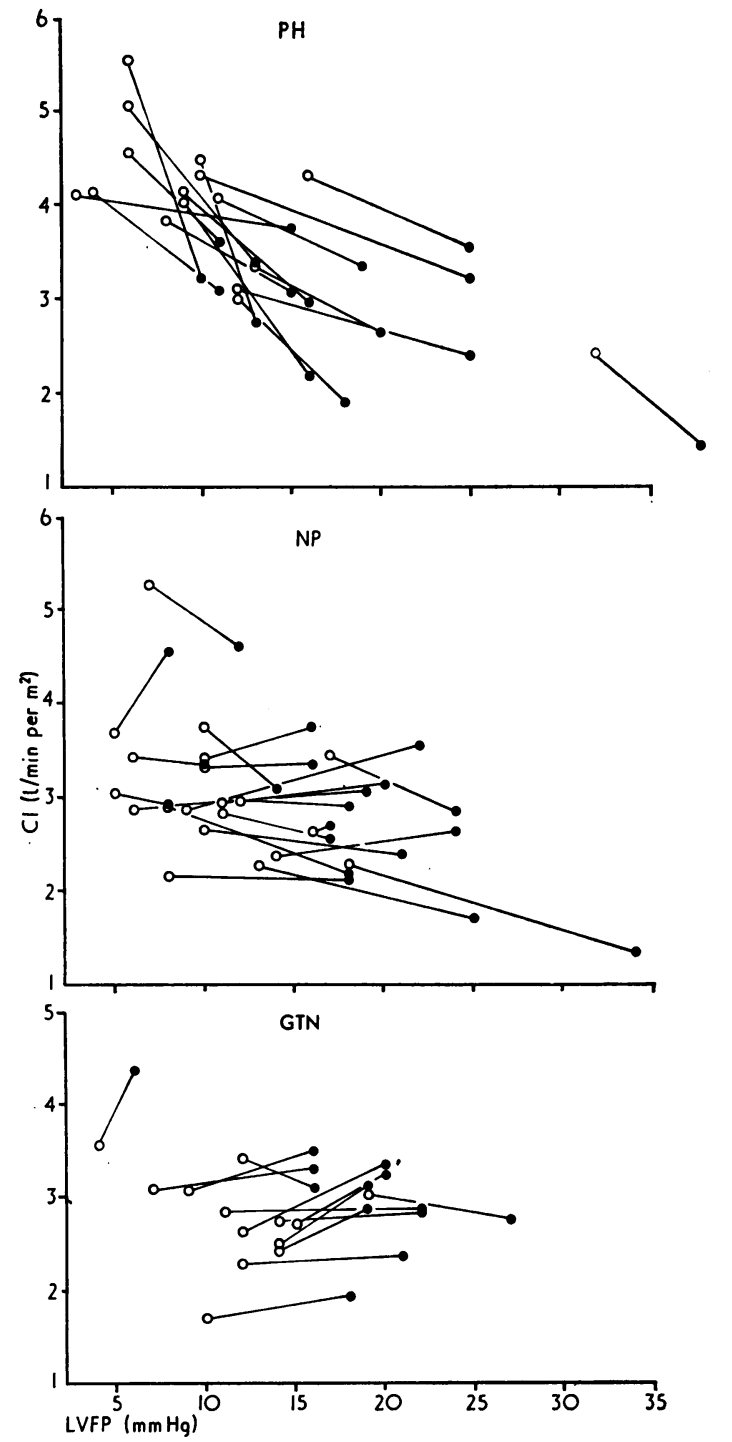

Fig. 3 Effects of phentolamine ( $P H)$, sodium nitroprusside (NP), and glyceryl trinitrate (GTN) on cardiac index (CI) and left ventricular filling pressure (LVFP) of all patients investigated. Individual patients are indicated by a line connecting a closed circle (control) with an open circle (under therapy).

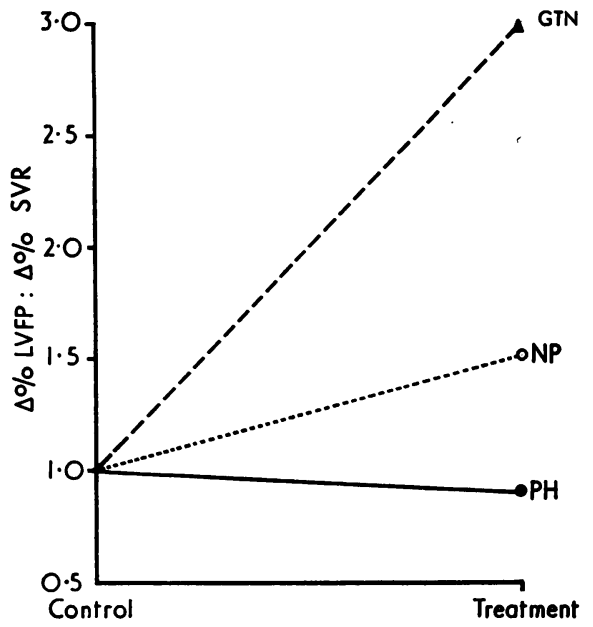

Fig. 4 Effects of phentolamine (PH), sodium nitroprusside (NP), and glyceryl trinitrate (GTN) on the ratio of percentage change in left ventricular filling pressure $(\triangle \% L V F P)$ to percentage change in systemic vascular resistance $(\Delta \% S V R)$.

Chatterjee et al. (1973) have doubted this mechanism. The authors referred to could not observe any positive inotropic effect of phentolamine in the isolated cat muscle. Increases of cardiac index with phentolamine have been found in patients with congestive heart failure with or without infarction (Gould et al., 1969; Majid et al., 1971; Perret et al., 1975; Miller et al., 1976), in patients with myocardial infarction and hypertension (Kelly et al., 1973), and with normotensive blood pressure (Gould et al., 1974). Walinsky et al. (1974), however, noted an increase of cardiac index only in patients with myocardial infarction and a left ventricular filling pressure above $15 \mathrm{mmHg}$. In our study we could not detect any dependence of phentolamine effect upon filling pressure (Fig. 3). The arteriolar vasodilating effect of phentolamine is caused by direct relaxing effect upon the smooth vascular muscle (Taylor et al., 1965). The ratio $\Delta \%$ LVFP/ $\Delta \%$ SVR shows that the influence of phentolamine on the arterioles clearly predominates when compared with its effect on the venous capacitance (Fig. 4).

Sodium nitroprusside caused a small, nonsignificant increase of the mean value of cardiac index with no change in the stroke volume. No clear relation between changes of cardiac index and the left ventricular filling pressure was apparent (Fig. 3). Likewise, changes in the cardiac index were not related to the filling pressure achieved under treatment. An unchanged stroke volume index despite a much decreased filling pressure implies a 
shift of the cardiac function curve to the left, which most probably results from the reduction of impedance to left ventricular outflow.

With vasodilator therapy, significant increase of the cardiac index in patients with severe congestive heart failure without infarction has been reported (Guiha et al., 1974; Froer et al., 1976; Kovick et al., 1976). Increase in cardiac output in normotensive patients with infarction, low cardiac index, and lung oedema has also been observed (Franciosa et al., 1972; Chatterjee et al., 1976). We can confirm this observation in some patients investigated with a low cardiac index. In keeping with our results, Franciosa et al. (1972) did not find any increase of cardiac index in patients with myocardial infarction who had a cardiac index above $2.5 \mathrm{l} / \mathrm{min}$ per $\mathrm{m}^{2}$ before treatment.

Compared with phentolamine, nitroprusside produced a distinctly smaller effect on the peripheral arteriolar resistance; the comparatively greater reduction of left ventricular filling pressure, as a result of the more pronounced effect on the venous capacitance, led to a significant increase of the ratio $\Delta \%$ LVFP $/ \Delta \%$ SVR (Fig. 4). The greater influence of nitroprusside on the venous capacitance became obvious in the direct comparison in the same patient, since at identical lowering of the arterial pressure the left ventricular filling pressure was lowered significantly more by nitroprusside than by phentolamine (Table 1, Fig. 1).

Glyceryl trinitrate, in our study, produced a significant decrease in stroke volume and cardiac index, even if left ventricular filling pressure was raised (Fig. 3, Tables 2 and 3). This is consistent with the findings in other studies (Come et al., 1975; Flaherty et al., 1976) which have shown, in acute myocardial infarction, a reduction of cardiac index during intravenous administration of glyceryl trinitrate, independent of the presence and severity of left ventricular failure. Similar results were reported by Williams et al. (1975) after sublingual administration of glyceryl trinitrate. Armstrong et al. (1975) did not find any significant changes in the cardiac index, whereas Bussmann et al. (1976) and Gold et al. (1972) described increases of cardiac index in patients with a high left ventricular filling pressure. The patients of Gold et al. (1972), however, were investigated within one week after acute myocardial infarction and Bussmann et al. (1976) did not specify exactly the time of their study in relation to the occurrence of infarction. In our patients, studied within 24 hours of the onset of symptoms, six had a left ventricular filling pressure of more than 20 $\mathrm{mmHg}$; only one showed a small increase of cardiac index. Compared with nitroprusside, glyceryl trinitrate lowered cardiac output probably as a consequence of the predominance of its preloadreducing action over its effect of reducing impedance (Fig. 4).

The mean dose of glyceryl trinitrate necessary to maintain the arterial pressure at the chosen level was $3 \mathrm{mg}$ per hour. This is in keeping with the doses given by other authors (Armstrong et al., 1975; Come et al., 1975; Flaherty et al., 1976). On account of the great variability of the dose necessary and to avoid wide swings of blood pressure, use of fixed infusion doses such as $6 \mathrm{mg}$ per hour (Bussmann et al., 1976) does not seem judicious to us. Cohen et al. (1973), Flaherty et al. (1975), Armstrong et al. (1975), and Miller et al. (1976) found that glyceryl trinitrate affects the vascular capacitance more than the vascular resistance. The ratio $\Delta \%$ LVFP $/ \Delta \%$ SVR in our patients confirmed these observations (Fig. 4). Of the three vasodilator drugs, glyceryl trinitrate had the least effect on the peripheral resistance. On the other hand, there was a distinct reduction of left ventricular filling pressure. According to Williams et al. (1975), falls of blood pressure produced by glyceryl trinitrate are mainly the result of a reduction of cardiac index. Only with higher doses does the lowering of systemic vascular resistance become more important (Flaherty et al., 1976).

\section{THERAPEUTIC IMPLICATIONS}

In patients with pump failure complicating acute myocardial infarction a primary aim of treatment is to increase cardiac output while reducing left ventricular filling pressure. On this basis phentolamine seems to be the drug of first choice in such patients. On the other hand, one major object of vasodilatory therapy in this situation is to limit the extent of tissue damage during the process of acute myocardial infarction. That implies augmenting cardiac index only to the extent just needed for a sufficient nutritional flow to the periphery. Increases in cardiac index to nearly $4 \mathrm{l} / \mathrm{min}$ per $\mathrm{m}^{2}$ as a mean value in several patients imply an overstimulation of the heart by phentolamine. In a study evaluating salvage of ischaemic myocardium by infusion of phentolamine for up to 48 hours, in most patients, we had to give practolol $10 \mathrm{mg}$ i.v. several times in order to lower cardiac index and/or heart rate (von Leitner et al., 1975).

In this study, within 24 hours after the onset of symptoms of acute myocardial infarction, glyceryl trinitrate reduced cardiac output, even in patients with a raised left ventricular filling pressure of more than $20 \mathrm{mmHg}$. Glyceryl trinitrate seems best suited for clinical application in the setting of severely raised filling pressure occurring concomi- 
tantly with preservation of normal cardiac output and arterial blood pressure. Without an initial rise of filling pressure pronounced decrease in ventricular preload at the expense of cardiac output may result in profound systemic hypotension (Williams et al., 1975). Unintentional overtreatment with nitroprusside can quickly be reversed by stopping or slowing the infusion rate, whereas glyceryl trinitrate has a longer lasting effect.

During nitroprusside infusion in the present investigation cardiac index and stroke volume index remained in a range which provided an adequate nutritional blood flow. Even with a fall in filling pressure to a range of 5 to $10 \mathrm{mmHg}$ the cardiac index and stroke volume index did not decline significantly and never to a critical amount. In patients with severe left ventricular failure intravenous nitroprusside usually improves the haemodynamic performance and considerably lowers the hospital mortality (Chatterjee et al., 1976). These results point to nitroprusside being optimally beneficial in the commonly encountered clinical situation. Whether phentolamine may be superior in severe cardiac failure because of its inotropic effect is not known. It seems desirable to widen the clinical experience with both drugs in patients with severe cardiac failure.

Although vasodilators improve haemodynamic performance, their effect on the acutely ischaemic myocardium is not well established. The reduction in preload and in afterload should lead to a diminution in the myocardial oxygen consumption requirements. Recently, Chatterjee et al. (1973) and Kötter et al. (1976) have reported a significant fall in myocardial oxygen consumption in acute myocardial infarction during the infusion of phentolamine, nitroprusside, and glyceryl trinitrate, respectively. This most probably has to be regarded as a beneficial effect in relation to reduced cardiac work.

It does not seem possible that the improved cardiac performance produced by vasodilator therapy could occur if it was accompanied by a deleterious effect on the overall myocardial oxygen metabolism as a result of lowered coronary perfusion pressure. However, the possibility of increased hypoxia in some areas of the myocardium because of reduction in local perfusion pressure still cannot be ruled out. In experimental animal studies, vasodilators have given variable results; however, the basic principle which is emerging is that the perfusion pressure to the ischaemic zone must be maintained. Conflicting results have also been obtained from clinical studies. Chiariello et al. (1976), for example, suggest that glyceryl trinitrate reduced ischaemic injury by increasing perfusion of the ischaemic areas, whereas nitroprusside may increase ischaemia. These reported results, however, still have to be confirmed. From the above and our own experience it seems that for clinical practice today no method sensitive enough to prove a beneficial effect on the ultimate infarct size is yet available (Schröder, 1976; Schröder et al., 1976). This difficulty, at least in part, may explain the contradictory results reported. At the present state of knowledge it seems advisable to us to limit vasodilator therapy in acute myocardial infarction to patients with raised arterial blood pressure and/or pump failure and pulmonary congestion until further studies have produced categorical evidence of beneficial effects in patients with uncomplicated myocardial infarction. Haemodynamic monitoring is not only essential for the selection of patients likely to benefit from such treatment but is also necessary to avoid complications such as an unexpected fall in arterial pressure.

\section{References}

Armstrong, P. W., Walker, D. C., Burton, J. R., and Parker, J. O. (1975). Vasodilator therapy in acute myocardial infarction. Circulation, 52, 1118-1122.

Bagwell, E. E., Hilliard, C. C., Daniell, H. B., Taylor, P. L., and Walton, R. P. (1970). Studies on the inotropic mechanism of phentolamine (abstract). American fournal of Cardiology, 25, 83.

Bussmann, W.-D., Schöfer, H., and Kaltenbach, M. (1976). Wirkung von Nitroglycerin beim akuten Myokardinfarkt. II. Intravenöse Dauerinfusion von Nitroglycerin bei Patienten mit und ohne Linksinsuffizienz und ihre Auswirkungen auf die Infarktgrösse. Deutsche medizinische Wochenschrift, 101, 642-648.

Chatterjee, K., Parmley, W. W., Ganz, W., Forrester, J., Walinsky, P., Crexells, C., and Swan, H. J. C. (1973). Hemodynamic and metabolic responses to vasodilator therapy in acute myocardial infarction. Circulation, 48, 1183-1193.

Chatterjee, K., Swan, H. J. C., Kaushik, V. S., Jobin, G., Magnusson, P., and Forrester, J. S. (1976). Effect of vasodilator therapy for severe pump failure in acute myocardial infarction on short-term and late prognosis. Circulation, 53, 797-802.

Chiariello, M., Gold, H. K., Leinbach, R. C., Davis, M. A., and Maroko, P. R. (1976). Comparison between effects of nitroprusside and nitroglycerin on ischemic injury during acute myocardial infarction. Circulation, 54, 766-773.

Cohen, M. V., Downey, J. M., Sonnenblick, E. H., and Kirk, E. S. (1973). The effects of nitroglycerin on coronary collaterals and myocardial contractility. Fournal of Clinical Investigation, 52, 2836-2847.

Come, P. C., Flaherty, J. T., Baird, M. G., Rouleau, J. R., Weisfeldt, M. L., Greene, H. L., Becker, L., and Pitt, B. (1975). Reversal by phenylephrine of the beneficial effects of intravenous nitroglycerin in patients with acute myocardial infarction. New England fournal of Medicine, 293, 1003-1007.

Dairman, W., Gordon, R., Spector, S., Sjoerdsma, A., and Udenfriend, S. (1968). Effect of $\alpha$-blockers on catecholamine biosynthesis (abstract). Federation Proceedings, 27, 240. 
Da Luz, P. L., Forrester, J. S., Wyatt, H. L., Tyberg, J. V., Chagrasulis, R., Parmley, W. W., and Swan, H. J. C. (1975). Hemodynamic and metabolic effects of sodium nitroprusside on the performance and metabolism of regional ischemic myocardium. Circulation, 52, 400-407.

Flaherty, J. T., Come, P. C., Baird, M. G., Rouleau, J., Taylor, D. R., Weisfeldt, M. L., Greene, H., L. Becker, L. C., and Pitt, B. (1976). Effects of intravenous nitroglycerin on left ventricular function and ST segment changes in acute myocardial infarction. British Heart fournal, 38, 612-621.

Flaherty, J. T., Reid, P. R., Kelly, D. T., Taylor, D. R., Weisfeldt, M. L., and Pitt, B. (1975). Intravenous nitroglycerin in acute myocardial infarction. Circulation, 51, 132-139.

Franciosa, J. A., Guiha, N. H., Limas, C. J., Rodriguera, E., and Cohn, J. N. (1972). Improved left ventricular function during nitroprusside infusion in acute myocardial infarction. Lancet, 1, 650-654.

Froer, K., Hall, D., Goppel, L., and Rudolph, W. (1976). Vasodilatatorische Therapie der chronischen Herzinsuffizienz. Verhandlungen der Deutschen Gesellschaft für innere Medizin, 1117-1119.

Gold, H. K., Leinbach, R. C., and Sanders, Ch. A. (1972). Use of sublingual nitroglycerin in congestive failure following acute myocardial infarction. Circulation, 46, 839-845.

Gould, L., Reddy, C. V. R., Kalanithi, P., Espina, L., and Gomprecht, R. F. (1974). Use of phentolamine in acute myocardial infarction. American Heart fournal, 88, 144148.

Gould, L., Zahir, M., and Ettinger, S. (1969). Phentolamine and cardiovascular performance. British Heart fournal, 31, 154-162.

Guiha, N. H., Cohn, J. N., Mikulic, E., Franciosa, J. A., and Limas, C. J. (1974). Treatment of refractory heart failure with infusion of nitroprusside. New England Fournal of Medicine, 291, 587-592.

Kelly, D. T., Delgado, C. E., Taylor, D. R., Pitt, B., and Ross, R. S. (1973). Use of phentolamine in acute myocardial infarction associated with hypertension and left ventricular failure. Circulation, 47, 729-735.

Kötter, V., v. Leitner, E. R., Wunderlich, J., and Schröder, R. (1976). Wirkungsvergleich von Phentolamin (Regitin), Natriumnitroprussid (Nipride) und Nitroglycerin bei der Behandlung des akuten Herzinfarktes. Intensivmedizin, 13, Suppl. 1, R. 52.

Kovick, R. B., Tillisch, J. H., Berens, S. C., Bramowitz, A. D., and Shine, K. I. (1976). Vasodilator therapy for chronic left ventricular failure. Circulation, 53, 322-328.
Majid, P. A., Sharma, B., and Taylor, S. H. (1971). Phentolamine for vasodilator treatment of severe heart-failure. Lancet, 2, 719-724.

Miller, R. R., Vismara, L. A., Williams, D. O., Amsterdam, E. A., and Mason, D. T. (1976). Pharmacological mechanisms for left ventricular unloading in clinical congestive heart failure. Differential effects of nitroprusside, phentolamine, and nitroglycerin on cardiac function and peripheral circulation. Circulation Research, 39, 127-132.

Perret, Cl., Gardaz, J.-P., Reynaert, M., Grimbert, F., and Enrico, J.-F. (1975). Phentolamine for vasodilator therapy in left ventricular failure complicating acute myocardial infarction. British Heart fournal, 37, 640-646.

Schröder, R. (1976). Rettung ischämischen Myokardgewebes beim Menschen? Intensivmedizin, 13, Suppl. 1, R. 5.

Schröder, R., Kötter, V., and von Leitner, E.-R. (1976). Attempt to prove salvage of ischemic myocardium in acute myocardial infarction. In 7th Congress of Cardiology, 20-25 fuly 1976, Amsterdam, Abstract book 1, 490.

Shell, W. E., Lavelle, J. F., Covell, J. W., and Sobel, B. E. (1973). Early estimation of myocardial damage in conscious dogs and patients with evolving myocardial infarction. Fournal of Clinical Investigation, 52, 2579-2590.

Singh, J. B., Hood, W. B., and Abelmann, W. H. (1970). Beta adrenergic mediated inotropic and chronotropic actions of phentolamine (abstract). American fournal of Cardiology, 26, 660.

Taylor, S. H., Sutherland, G. R., MacKenzie, G. J., Staunton, H. P., and Donald, K. W. (1965). The circulatory effects of intravenous phentolamine in man. Circulation, 31, 741754.

von Leitner, E. R., Kötter, V., and Schröder, R. (1975). Beeinflussung der Infarktgrösse durch Senkung der Herzarbeit bei akutem Myokardinfarkt. Zeitschrift für Kardiologie, Suppl. II, 58.

Walinsky, P., Chatterjee, K., Forrester, J., Parmley, W. W., and Swan, H. J. C. (1974). Enhanced left ventricular performance with phentolamine in acute myocardial infarction. American Fournal of Cardiology, 33, 37-41.

Williams, D. O., Amsterdam, E. A., and Mason, D. T. (1975). Hemodynamic effects of nitroglycerin in acute myocardial infarction: decrease in ventricular preload at the expense of cardiac output. Circulation, 51, 421-427.

Requests for reprints to Professor R. Schröder, Hindenburgdamm 30, 1 Berlin 45, Germany. 